\title{
Potential of Dayak Onion (Eleutherine palmifolia (L) Merr) Extract As Antibacterial Against Pseudomonas fluorescens
}

\author{
Immaria Fransira ${ }^{1 *}$, Uun Yanuhar ${ }^{2}$, Maftuch $^{2}$ \\ ${ }^{1}$ Master Program of Aquaculture, Faculty of Fisheries and Marine Science, University of Brawijaya, Malang, Indonesia \\ ${ }^{2}$ Faculty of Fisheries and Marine Science, University of Brawijaya, Malang, Indonesia
}

\begin{abstract}
Dayak onions (E. palmifolia (L) Merr) is a herb used as medicine and known to have antibacterial activity. This research aimed to evaluate antibacterial activity of Dayak onion (Eleutherine palmifolia (L) Merr) extract against fish pathogen Pseudomonas fluorescens. The method used in this study was extraction by maceration, UV-Vis spectrophotometry analysis on the extract and antibacterial activity test with Minimum Inhibitory Concentration (MIC) as well as disc diffusion test. The results of this study showed that the yield value was $8.87 \%$. Based on UV-Vis analysis, it confirmed that extract of Dayak onion (Eleutherine palmifolia (L) Merr) contains predominantly flavonoids and phenols with its derivatives, that have antibacterial activity. The results of MIC and disc diffusion test showed potential antibacterial activity against $P$. fluorescens, as observed from the value of absorbance and inhibition zones that formed.
\end{abstract}

Keywords: Antibacterial, Disc diffusion, Eleutherine palmifolia (L) Merr, MIC, Pseudomonas fluorescens.

\section{INTRODUCTION}

Pseudomonas fluorescens is a gram negative bacterium that is pathogenic to fish, thus causing the disease in fish [1]. P. fluorescens is not only causes hemorrhage on the skin and fins, but also damages gills, kidney, and liver, which leads to fish death [2]. Infection of pathogenic bacteria such as $P$. fluorescens will cause economic losses to aquaculture industries [3].

One of the herbs that can be used against $P$. fluorescens is Dayak onion (Eleutherine palmifolia (L) Merr). Dayak onion grows in Borneo mountainous areas with green leaves and red bulbs like red onion [4]. The onion is known to contain alkaloids, flavonoids, phenolics, tannins, and triterpenoids, which have a function as antimicrobials [5]. This onion ethanol extract showed positive results on flavonoids, phenolics, alkaloids, saponins, and triterpenoids [6].

Other studies have previously proven that extract of Dayak onion bulbs was able to inhibit $P$. fluorescens bacteria through the Minimum Inhibitory Concentration (MIC) test [7]. The ethanol extract with a concentration of $1 \%$ was also able to inhibit the growth of $S$. aureus and with a concentration of $15 \%$ can inhibit the bacteria T. rubrum [8]. However, there is no study reported on the effect of the Dayak onion extract towards inhibition zone of $P$. fluorescens bacteria. Based on these facts, the aim of this research was to evaluate the antibacterial

\footnotetext{
* Correspondence address: Immaria Fransira

Email : immariafransira@gmail.com

Address : University of Brawijaya, Veteran Malang 65145.
}

activity of Dayak onion (Eleutherine palmifolia (L) Merr) extract against Pseudomonas fluorescens bacteria.

\section{MATERIAL AND METHOD \\ Extraction}

Dayak onion bulbs (Eleutherine palmifolia (L) Merr) obtained from UPT Materia Medica Batu were extracted by maceration and the values of the yield were calculated [9]. $100 \mathrm{~g}$ of simplicia were mixed with $600 \mathrm{~mL}$ of ethanol (PA) solvent and left to stand for three days. The mixture was filtered with Whatman filter paper (No. 42). Then, the filtrate was concentrated with a vacuum rotary evaporator at $50^{\circ} \mathrm{C}$ until a thick extract was obtained. The yield value was determined by calculating the final weight of extract compared to the weight of the initial simplicia.

\section{UV-Vis Spectrophotometry Analysis}

UV-Vis spectrophotometry analysis was carried out by measuring the absorbance of UV wavelength spectra of the extract with a spectrophotometer [10]. The extract was transferred into the cuvet then scanned with a spectrophotometer with a resolution of $1 \mathrm{~nm}$ (from 200 to $800 \mathrm{~nm}$ ). The obtained graph was analyzed for presence of active compounds.

\section{Bacterial Culture}

Pure culture of Pseudomonas fluorescens bacteria was obtained from the Brackishwater Aquaculture Center (BBPBAP) Jepara. Before being used for the antibacterial test, the bacterium was cultured in liquid medium [11]. The rejuvenated bacterial culture was inoculated 
using a needle loop, into Tryptone Soya Broth (TSB) medium. The inoculated medium was then incubated for 24 hours $\left(37^{\circ} \mathrm{C}\right)$. After 24 hours growth, the culture was ready to be used for antibacterial testing.

\section{Minimum Inhibitory Concentration (MIC)}

The MIC test was adopted from Nordin et al., 2019 [12]. Preparation of the MIC test was carried out by preparing sterile test tubes according to the concentration to be used along with negative control of $P$. fluorescens and positive control containing $30 \mathrm{ppm}$ chloramphenicol. The concentrated extract which has been dissolved with $10 \%$ DMSO at a predetermined concentration was transferred as much as $1 \mathrm{~mL}$ into a test tube containing the medium at the treatment of each concentration then [12]. Extract of Dayak onion with concentrations of 1000 ppm, 500 ppm, 100 ppm, $10 \mathrm{ppm}$, and $1 \mathrm{ppm}$ were transferred into sterile test tubes. Then each tube was inoculated with 1 $\mathrm{mL}$ of $P$. fluorescens bacterial isolate from previous liquid medium (TSB) and incubated at $37^{\circ} \mathrm{C}$. After 24 hours, the optical density of each tube was measured with a spectrophotometer with a wavelength of $600 \mathrm{~nm}$. The data were analyzed to determine the MIC value.

\section{Disc Diffusion Test}

The disc diffusion test was performed according Sekar and Rashid [13] to measure the inhibition zone occurred around the disc paper that has been given Dayak onion (Eleutherine palmifolia (L) Merr) extract. Bacterial isolate at a density of $10^{6}$ CFU $\mathrm{mL}^{-1}$ was spread on Pseudomonas Selective Agar Base (PSA) medium . Further, paper discs were soaked in Dayak onion extract which had dissolved using $10 \%$ DMSO to get the concentration of 1000 ppm, $500 \mathrm{ppm}, 100 \mathrm{ppm}, 10 \mathrm{ppm}$ and $1 \mathrm{ppm}$. The discs were placed in the middle of the agar media which has been inoculated with the bacterial culture. Petri dishes were incubated for
24 hours at $37^{\circ} \mathrm{C}$, and the clear zones were measured using digital calipers.

\section{RESULT AND DISCUSSION \\ Extract of Dayak Onion}

The extraction of Dayak onion obtained $8.87 \mathrm{~g}$ crude extracts. Hence, the yield was $8.87 \%$. This showed that the secondary metabolites contained in the onion extract were dominated by the polar group. Ethanol are the best solvents that can extract almost all low molecular weight compounds such as flavonoids, alcohols, and saponins [14]. The ethanol extract has a higher extract weight than to other solvents. Also, polar solvents such as ethanol extract phenolic compounds from these plants, with more yield [15].

\section{UV-Vis Analysis}

Result of UV-Vis analysis on Dayak onion extract was presented in Figure 1. Based on the graph obtained through UV-Vis spectrophotometer it can be analyzed the absorbance values on wavelengths of 202.0, 204.1, 205.9, 208.9, 212.1, 215.1, 216.9, 222.0, 224.9, 231.0, 234.0, 237.9, 242.0, 245.0 and $367.1 \mathrm{~nm}$. It is known that the value of these wavelengths is a group of flavonoids and phenols with its derivatives [16-17]. It confirmed that Dayak onion extract contains dominant compounds from flavonoids and phenols as well as its derivatives. Flavonoids are known to work as antibacterial. This compound denature proteins that will stimulate the cell destruction of bacterial cells and eventually cause lysis of bacteria [18]. The antibacterial activity can also be explained by the inhibition of bacterial metabolism and absorption of substances needed for bacterial growth [19]. Phenol compounds will disrupt the permeability of gramnegative bacterial cell membranes and interfere with the work system of bacterial metabolism [20].

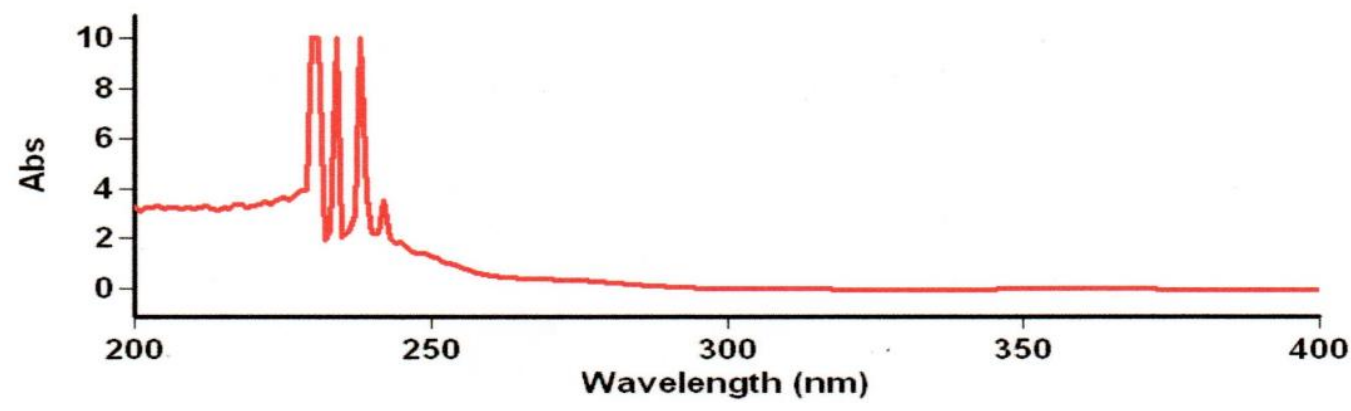

Figure 1. UV-Vis Analysis Result of Dayak Onion (Eleutherine palmifolia (L) Merr) Extract 


\section{Minimum Inhibitory Concentration (MIC)}

MIC test was carried out to determine the minimum concentration that can inhibit bacterial growth. MIC results of Dayak onion extract on $P$. fluorescens bacteria can be seen in Table 1.

Table 1. MIC Result of Dayak Onion (E. palmifolia (L) Merr) Extract against $P$. fluorescens

\begin{tabular}{ccc}
\hline $\begin{array}{c}\text { Concentration } \\
\text { (ppm) }\end{array}$ & Absorbance & Turbidity \\
\hline 1000 & 0.292 & Quite Clear \\
500 & 0.376 & Quite Clear \\
100 & 0.328 & Quite Clear \\
10 & 0.192 & Quite Clear \\
1 & 0.602 & Turbid \\
Negative Control & 1.161 & Turbid \\
Positive Control & 0.088 & Clear \\
\hline
\end{tabular}

Based on the results of the MIC, it can be seen that the concentration of $10 \mathrm{ppm}$ had an absorbance value lower than $100 \mathrm{ppm}$ and approached the absorbance value of positive control. This shows that $10 \mathrm{ppm}$ concentration of the extract can inhibit Pseudomonas fluorescens bacteria. The low absorbance value indicated no bacterial growth or inhibited bacterial growth [21]. The high and low concentrations of extract that causes differences in the MIC value, so it can be seen there is a presence or absence of bacterial growth [22]. Previous study stated that Dayak onion extract contained other metabolites like tannins which are derivatives of the phenolic group [23]. Phenol is an antibacterial compound that has the ability to damage bacterial cells and inhibit bacterial growth. Tannins, as its derivates can bind with lipoteichoic on the surface of bacteria [24]. Tannins can agglomerate bacterial cytoplasmic cells so that the metabolism of bacteria will be disrupted [25].

\section{Disc Diffusion Test}

The results of the disc diffusion test, showed the clear zone (inhibition zone) formed by different bacterial inhibition categories, such as very strong, strong, medium and weak [26], which can be seen in Table 2.

Table 2. Disc Diffusion Test Result of Dayak Onion ( $E$. palmifolia (L) Merr) Extract against $P$. fluorescens

\begin{tabular}{ccc}
\hline $\begin{array}{c}\text { Concentration } \\
(\mathbf{p p m})\end{array}$ & $\begin{array}{c}\text { Clear Zone } \\
\text { Diameter }(\mathbf{m m})\end{array}$ & $\begin{array}{c}\text { Inhibitory } \\
\text { Categorial }\end{array}$ \\
\hline 1000 & $13.04 \pm 0.21$ & Strong \\
500 & $11.37 \pm 0.52$ & Strong \\
100 & $10.79 \pm 0.32$ & Strong \\
10 & $9.23 \pm 0.54$ & Medium \\
1 & $6.10 \pm 0.04$ & Medium \\
\hline
\end{tabular}

In these results, it can be seen that the onion extract has antibacterial activity. Where the clear zone formed indicated inhibition of bacterial growth [27]. It showed that the higher the concentration of extract, the greater the clear zone formed, with the largest clear zone at a concentration of $1000 \mathrm{ppm}$, which is $13.04 \pm 0.21$ $\mathrm{mm}$. Other studies previously showed that Dayak onion extract was able to inhibit pathogenic bacteria such as Staphylococcus aureus, Pseudomonas aeruginosa, Shigella sp. and Bacillus cereus, with concentrations of extract was $10 \mathrm{ppm}$ [28]. This depends on the content of secondary metabolites that contained in that onion. Based on this study, the onion extract contains flavonoids and phenols compound along with its derivatives which are known to have antibacterial activity.

Flavonoids as antibacterial have three ways of working, the first by inhibiting nucleic acid synthesis, the second is by inhibiting cytoplasmic membrane function and the third by inhibiting energy metabolism [29,30]. Phenol can inhibit bacteria by destroying the plasma membrane. Where the damage of that cell membranes can prevent food or nutrients needed by bacteria to produce energy, resulting in inhibition of growth or even death [31]. In general, the work of antibacterial compounds cause membrane permeability disorder that lead to leakage of the cytoplasmic membrane. Cytoplasmic membranes can become damaged and functionally deactivated when bacteria are exposed to antibacterial agents. So the material of the intracellular will leak out that results in the damage on large molecules in bacteria [32].

\section{CONCLUSION}

The extract of Dayak onion (Eleutherine palmifolia (L) Merr) showed the presence of antibacterial compound such as flavonoids and phenols along with its derivatives. The crude extract inhibited the growth of Pseudomons fluorescens bacteria, where the MIC results that obtained was at $10 \mathrm{ppm}$ of concentration. Based on the disc diffusion test, it was found that the extract concentration will affect the antibacterial activity in inhibition.

\section{REFERENCES}

[1] Wamala, S.P., K.K. Mugimba, S. Mutoloki, O. Evensen, R. Mdegela, D.K. Byarugaba, H. Sorum. 2018. Occurrence and antibiotic susceptibility of fish bacteria isolated from Oreochromis niloticusis (Nile Tilapia) and 
Clarias gariepinus (African Catfish) in Uganda. Fish. Aquat. Sci. 21(6). 1-10.

[2] Darak, O., R.D. Barde. 2015. Pseudomonas fluorescens associated with bacterial disease in Catla catla in Marathwada Region of Maharashtra. Int. J. Adv. Biotech. Res. 6(2). 189-195.

[3] Kader, M.F.A.E., T.M.M. Balabel. 2017. Isolation and molecular characterization of some bacteria implicated in the seasonal summer mortalities of farm-raised Oreochromis niloticus at Kafr El-Sheikh and Dakahlia Governorates. Alex. J. Vet. Sci. 53(2). 107-113.

[4] Duweini, M., R. Trihaditia. 2017. Penentuan formulasi optimum pembuatan minuman fungsional dari Bunga Rosella (Hibiscus sabdariffa L.) dengan penambahan Bawang Dayak (Eleutherine palmifolia (L) Merr.) menggunakan metode RSM (Response Surface Method). Agroscience. 7(2). 234248.

[5] Galingging, R.Y. 2006. Potensi plasma nutfah tanaman obat sebagai sumber biofarmaka di Kalimantan Tengah. Jurnal Pengkaji dan Pengembangan Teknologi Pertanian. 10(1). 76-83.

[6] Setiawan, N.C.E., A. Febriyanti. 2017. Aktivitas antioksidan ekstrak etanol dan fraksi-fraksi Umbi Eleutherine palmifolia (L.) Merr Bulbs dengan metode DPPH. J. Curr. Pharm. Sci. 1(1). 1-5.

[7] Maftuch. 2017. Effect of Bawang Dayak (Eleutherine palmifolia (L) Merr) crude extract towards bacteria inhibition zone and Carp (Cyprinus carpio) hematology. Am. Inst. Physics Conf. Proc. 1844(1). 1-7.

[8] Puspadewi, R., P. Adirestuti, R. Menawati. 2013. Khasiat umbi Bawang Dayak (Eleutherine palmifolia (L.) Merr) sebagai herbal antimikroba kulit. Kartika Jurnal Ilmiah Farmasi. 1(1). 31-37.

[9] Wicaksono, I.A., D. Runadi, I. Firmansyah. 2018. Antibacterial activity test of Dayak Onions (Eleutherine palmifolia L. Merr) ethanolic extract against Shigella dysenteriae ATCC 13313. National J. Physiol. Pharm. Pharmacol. 8(5). 1-4.

[10] Jain, P.K., A. Soni, P. Jain, J. Bhawsar. 2016. Phytochemical analysis of Mentha spicata plant extract using UV-VIS, FTIR and GC/MS Technique. J. Chem. Pharm. Res. 8(2). 1-6.

[11] Vu, T.T., H. Kim, V.K. Tran, Q.L. Dang, H.T. Nguyen, H. Kim, I.S. Kim, G.J. Choi, J.C. Kim. 2016. In Vitro antibacterial activity of selected medicinal plants traditionally used in Vietnam against human pathogenic bacteria. BMC Complement. Altern. Med. 16(32). 1-6.

[12] Nordin, M.L., A.A. Othman, A.A. Kadir, R. Shaari, A.Y. Osman, M. Mohamed. 2019. Antibacterial and cytotoxic activities of the Syzygium polyanthum leaf extract from Malaysia. Vet. World. 12(8). 236-242.

[13] Sekar, M., N.A. Rashid. 2016. Formulation, evaluation and antibacterial properties of herbal oinment containing methanolic extract of Clinacanthus nutans Leaves. Int. J. Pharm. Clin. Res. 8(8). 1170-1174.

[14] Arifianti, L., R.D. Oktarina, I. Kusumawati. 2014. Pengaruh jenis pelarut pengekstraksi terhadap kadar sinentesin dalam ekstrak daun Orthosiphon stamineus Benth. EJournal Planta Husada. 2(1). 1-4.

[15] Hidayah, N., A.K. Hisan, A. Solikin, Irawati, D. Mustikaningtyas. 2016. Uji efektivitas ekstrak Sargassum muticum sebagai alternatif obat bisul akibat aktivitas Staphylococcus aureus. Journal of Creativity Students. 1(1). 1-9.

[16] Harbone, J. 2006. Metode fitokimia: penuntun cara modern menganalisis tumbuhan, $2^{\text {nd }}$ Ed. Padmawinata K., I. Soediro (TransI). ITB Press. Bandung.

[17] Janakiraman, M., K. Jeyaprakash. 2015. Evaluation of phytochemical compounds in leaf extract of Vitex negundo L. using TLC, UV-VIS and FTIR Analysis. Int. J. Health Sci. Res. 5(8). 289-295.

[18] Armanda, F., M.Y. Ichrom N., L.Y. Budiarty. 2017. Efektivitas daya hambat bakteri ekstrak Bawang Dayak terstandarisasi flavonoid terhadap Enterococcus faecalis In Vitro. Dentino. 2(2). 183-187.

[19] Abed, I.J., R. Al-Moula, G. A. Abdulhasan. 2015. Antibacterial effect of flavonoids extracted from seeds of Silybum marianum against common pathogenic bacteria. World J. Exp. Biosci. 3(1). 36-39.

[20] Febriyani, E., S. Falah, D. Andrianto, T. Lastini. 2018. Identification of active compounds and anti-acne activity from extracts and fractions of Surian (Toona sinensis) leaves planted in Sumedang, West Java, Indonesia. Biodiversitas. 19(4). 14061412.

[21] Mummed, B., A. Abraha, T. Feyera, A. Nigusse, S. Assefa. 2018. In Vitro antibacterial activity of selected medicinal plants in the traditional treatment of skin 
and wound infections in Eastern Ethiopia. BioMed Res. Int. 1. 1-8.

[22] Nirwana, I., D. Rianti, R.H. Soekartono, Rr. D. Listyorini, D.P. Basuki. 2018. Antibacterial activity of Fig Leaf (Ficus carica Linn.) extract against Enterococcus faecalis and its cytotoxity effects on fibroblast cells. Vet. World. 11(3). 342-347.

[23] Chabib, L., W.K. Muhtadi, M.I. Rizki, R.A. Rahman, M.R. Suhendri, A. Hidayat. 2018. Potential medicinal plants for improve the immune system from Borneo Island and the prospect to be developed as nanomedicine. EDP Sciences. 154. 1-6.

[24] Doss, A., H.M. Mubarack, R. Dhanabalan. 2009. Antibacterial activity of tannins from the leaves of Solanum trilobatum Linn. Indian J. Sci. Tech. 2(2). 41-43.

[25] Alabi, O.A., M.T. Haruna, C.P. Anokwuru, T. Jagede, H. Abia, V.E. Okegbe, B.E. Esan. 2012. Comparative studies on antimicrobacial properties of extracts of fresh and dried leaves of Carica papaya L. on clinical bacterial and fungi isolates. Adv. Appl. Sci. Res. 3(5). 3107-3114.

[26] Ulmursida, A., A. Ambariyanto, A. Trianto. 2017. Antibacterial activity of mangrove Avicennia marina extract against Virgibacillus marismortui and Micrococcus luteus Bacteria. AACL Bioflux. 10(2). 372380.

[27] Sholihah, I., I. Trisharyanti D. K. 2017. Antibacterial activity of ethanolic extract and infusion of Bauhinia variegata leaves against Streptococcus pyogenes. Pharmacon. 18. 1-7.

[28] Harlita, T.D., Oedjijono, A. Asnani. 2018. The antibacterial activity of Dayak Onion (Eleutherine palmifolia (L.) Merr) towards pathogenic bacteria. Trop. Life Sci. Res. 112.

[29] Vasconcelos, L.C.S., F.C. Sampaio, M.C.C. Sampaio, M.S.V. Pereira, J.S. Higino, M.H.P. Peixoto. 2006. Minimum inhibitory concentration of adherence of Punica granatum Linn (Pomegranate) gel againts $S$. mutans, S. Mitis and C. albicans. Braz Dent. J. 17(13). 223-227.

[30] Nalini, S., D.S. Richard, S.U.M. Riyaz, G. Kavitha, D. Inbakandan. 2018. Antibacterial macro molecules from marine organisms. Int. J. Biol. Macromol. 115. 696-710.

[31] Mailoa, M.N., M. Mahendradatta, A. Laga, N. Djide. 2014. Antimicrobial activities of tannins extract from Guava Leaves (Psidium guajava L) on pathogens microbial. Int. J. Sci. Tech. Res. 3(1). 236-241.

[32] Naufalin, R., S.R. Herastuti. 2017. Antibacterial activity of Nicolaia speciosa fruit extract. Int. Food Res. J. 24(1). 379-385. 